\title{
Powerful knowledge, myth or reality? Four necessary conditions if knowledge is to be associated with power and social justice
}

Priscilla Alderson (D)

\section{How to cite this article}

Alderson, P. (2020) 'Powerful knowledge, myth or reality? Four necessary conditions if knowledge is to be associated with power and social justice'. London Review of Education, 18 (1): 96-106. https://doi.org/10.18546/LRE.18.1.07

Submission date: 15 January 2019

Acceptance date: 3 October 2019

Publication date: 1 March 2020

\section{Peer review}

This article has been peer reviewed through the journal's standard double-blind peer review, where both the reviewers and authors are anonymized during review.

\section{Copyright}

(C) Copyright 2020 Alderson. This is an Open Access article distributed under the terms of the Creative Commons Attribution Licence (CC BY) 4.0 https://creativecommons.org/licenses/by/4.0/, which permits unrestricted use, distribution and reproduction in any medium, provided the original author and source are credited.

\section{Open access}

London Review of Education is a peer-reviewed open-access journal. 


\title{
Powerful knowledge, myth or reality? Four necessary conditions if knowledge is to be associated with power and social justice
}

\author{
Priscilla Alderson* - UCL Institute of Education, UK
}

\begin{abstract}
Can knowledge be powerful and, if so, what forms do knowledge and power take? The view of some social realist curriculum theorists that power exists in academic theories although not in everyday understanding is questioned. Power is taken to exist through social positions, and to involve control over resources, decisions and change. Critical realist analysis suggests that four conditions are necessary if knowledge is to be associated with power: the known, the knowers, the social contexts and the practical application of knowledge. Questions are considered about how today's schools can promote learning and social justice.
\end{abstract}

Keywords: critical realism, everyday experience, learning, teaching, social contexts, social justice

\section{Introduction}

Powerful knowledge (PK) is a much-discussed concept of a group of curriculum theorists. They contend that power exists as PK in academic disciplines, and that social justice is promoted by respecting all school students' entitlement to be taught PK (for example, Gericke et al., 2018; Hoadley et al., 2019; Lambert, 2018; Moore, 2013; Wheelahan, 2010; Young, 2008, 2014; Young and Muller, 2016; Young et al., 2016; Muller and Young, 2019). Yet can knowledge be powerful and, if so, under what conditions? Power is taken in this article to exist through social relationships and positions in power over resources and decisions, and over making or resisting change (Lukes, 2005; Weber, 2013). Social justice involves more than equal opportunities (such as to PK) and means greater equality and shared political power throughout society (Molyneux, 2012). PK theory was developed within social realism, which is said to be influenced by critical realism (Moore, 2013; Wheelahan, 2010; Young, 2008). Social and critical realism share concerns that interpretive social research tends towards unhelpful relativism. Yet critical realism provides valuable concepts that are not used in PK social realism and that inform this article.

Critical realists ask, 'What must the world be like for a certain thing or process to exist?' (Bhaskar, 1998, 2008). Applying this question to PK shows that abstract knowledge alone is powerless because social power depends on human agency (Archer, 2000). I propose that if knowledge is to be associated with power and social justice, four conditions are necessary: the known or knowledge; the knowers as individuals and groups; the social contexts that enable or constrain the knowers; and the practical application of knowledge. After reviewing the four conditions, I will consider the kinds of knowledge that today's schools need to nurture in order to promote social justice. 


\section{The known}

The first condition, if knowledge is to be associated with power, is the type of knowledge to be known. PK theorists associate power with 'the formal, codified, theoretical and at least potentially generalising universalising knowledge of the curriculum' (Young and Muller, 2016: 12), which exists most clearly in the natural sciences. 'We have extended the meaning and range of "power" ... to include the social sciences, humanities and the arts', but if these are to qualify as PK, they must meet criteria set in the natural sciences: 'methodological rigour', objectivity, being free from 'non-specialist contaminants' but having highly specialized disciplines 'policed by the relevant peer community' (ibid.: 132-3). Topping a hierarchy of 'better', more generalizable, reliable, accurate, universal and predictable knowledge, are the natural sciences. The humanities 'compare less and less favourably, on universal criteria' with them (ibid.: 118-9). Lowest in the hierarchy is 'informal, local and everyday experiential knowledge' (ibid.), seen as too contingent to be informed by universalizing analysis. It is assumed, thereby, to narrow students' thinking and therefore to limit their access to real knowledge and the power it confers (ibid.). Power seems to be equated with rigorous scientific theories and analysis. Besides providing more reliable explanations, PK is supposed to 'provide learners with a language for engaging in political, moral and other kinds of debates' (Young, 2008: 14), although it is not clear which disciplines will provide this language.

Critical realists understand knowledge and reality at three levels (Bhaskar, 1998). The empirical level is our sensed experiences, perceptions and interpretations, our thinking and talking. The actual level includes actual activities, events, people, objects, relations and structures, the being and doing of the independent real world, an infinite reality that we can know only slightly and fallibly. At the third level, the real, are powerful causal mechanisms usually only seen in their effects. Natural causal mechanisms unseen by the naked eye include gravity, microbes, molecular and genetic structures. Social causal mechanisms include human values and motives, justice and inequalities of class and race (Bhaskar, 2008; Porpora, 2015). PK theorists examine all three levels, although, apart from stated concern about social justice, they tend to avoid discussions about social mechanisms.

Most research collapses the independent actual and real levels into the empirical or knowledge level (Bhaskar, 1998). Instead of the original realities being researched, interpretive research emphasizes perceptions and social constructions, and positivism emphasizes facts (truth claims) and statistics. Critical realists consider this is an epistemic fallacy to reduce ontology (being and doing) into the epistemology (thinking, knowledge) that represents it. PK theory does so by positioning the power necessary to promote social justice within knowledge, and away from agents and resources. Knowledge exists in empirical human thought and communication. Its symbols exist in actual books and other records. And knowledge is used to understand and explain processes at the actual and real levels of natural and social activity. Yet knowledge itself exists only at the first empirical level. It is general and amorphous, dependent on how it is presented and perceived, often misunderstood and contested, as the Brexit debates show.

Critical realism and social realism both consider that the content of knowledge constantly changes and emerges through research and creativity (Bhaskar, 2008; Moore, 2013; Wheelahan, 2010; Young, 2008; Young and Muller, 2016). However, social realism takes the most powerful forms of knowledge to be fixed insights, with 'objective longevity' (Young and Muller, 2016: 116, 129), such as Euclid's theorem (Young, 2008: 28). When PK concepts change through new analysis, they should move 
nearer to final reliable truths. Two main influences on PK theory are long-lasting: Durkheim's (1995) theories of sacred versus profane knowledge, and Bernstein's (2000) elaborated or restricted codes of language. Young and Muller (2016: 38) contend that $\mathrm{PK}$, in its abstract structures, bounded single-discipline systems and grammars, engages with ideas of certainty, reliability, objectivity and even truth. They believe, therefore, that PK has authority to license a whole range of education policies. Yet there are complications in privileging formal abstract knowledge over everyday secular knowledge, discussed later.

Knowledge is more than organized thought when its content and substance draw mainly on the independent social and natural worlds. 'Practices of knowing cannot fully be claimed as human practices, not simply because we use non-human elements in our practices but because knowing is a matter of part of the world making itself intelligible to another part' (Barad, 2007: 185). 'Our entanglement [or dialectic] with the world, both human and non-human, both material and discursive, is what constitutes knowledge: as researchers we are part of the world we study' (Spyrou, 2018: 9).

Social realism attributes power specifically to (abstract, objective, conceptual) knowledge, the known. However, knowledge alone cannot exercise power, which partly depends on the agency of the knowers.

\section{The knowers}

The concept of singing recognizes differences between songs and singers. Knowing involves differences between knowledge and knowers. The critical realist Margaret Archer (1988: xvi) sees singing as a reminder of crucial differences between culture (including knowledge) and agents, whereas PK curriculum theorists tend to say little about the agency of the knowers, the teachers and students, and their interactions, and suggest a general sense of uncritical students absorbing the curriculum fairly passively. However, Deng (2015) and Gericke and colleagues (2018) do connect curricula and pedagogy to unlock and examine transformation as a process of knowledge. Yet they only consider schools, not society, so that connections between PK, power and justice are unclear. These authors also emphasize impersonal processes rather than specific agents. The concept of PK suggests determinism, that knowledge is a determining social or cultural structure, bestowing power on relatively passive agents. Archer (1988) criticizes determinism, and also the converse imbalance in social research of voluntarism, when overly free agents seem to shape weak social structures. Instead, Archer examines the power relations when agents are enabled and also constrained by strong social structures (such as education systems or schools), which nevertheless can only exist through being reproduced or modified by human agents. PK is a cultural entity, not an enduring social structure (like a school) because it has no physical existence. It is abstract, lost and forgotten, inside books for example, and only activated when agents recall and study the knowledge in books, discussions or online.

And supposedly objective knowledge is always subject to each knower's subjective interpretation and re-presentation. So to separate PK curricula from the agency of teachers and learners evades these and other vital questions about interdependent relations between the knowers and the known, and the knowers' agency when they select and design curricula, or teach, learn, and interpret them, or resist, alter or elaborate on the knowledge in the curricula. Such processes are central to critical realism's concern to understand causal influences and their effects, by examining structure-agency interactions through transformative change over time (Archer, 1988, 2000; Bhaskar, 2008). 
The word 'knowledge' is derived from an Anglo-Saxon verb, neahlaechen, to acknowledge, recognize or approach, and the noun, lac, game, play, sport, suggesting that knowledge is information and skills acquired through the knowing agents' experience, education and play. Most of the infinite human knowledge, which has been or could be known - whole languages and libraries - are lost. Knowledge can only be connected to power when the knowers actively recall or access it, and when they at least partly understand and apply it. A theory of knowledge therefore has to respect the knowers, including thinkers, inventors, imaginers, creators, teachers, listeners and learners.

PK theory is influenced by Bernstein (2000) and his colleague Peters (1972). Following Durkheim (1995), they assumed that all knowledge is cultural, social and acquired only through language, when adults teach and reason with children mainly after the supposedly pre-rational, pre-moral first six years, when children are 'persons in the making' not 'the best or even the most appropriate guardians of their own interests ... they need protection from themselves as well as from others' (Brighouse, 2000: 11). This view supports PK theorists' repeated assertion that school students cannot be trusted to choose their own curriculum (Young and Muller, 2016: 72), as if they are rationally and morally unreliable. In the Durkheimian functionalist tradition (which assumes current society functions for the common good), morality is derived from social norms into which children must be socialized, often with great difficulty (Peters, 1972), when they gradually learn 'right from wrong', and study to follow the rules. The good child does not ask rebellious questions. Independent ideas about morality are discouraged when schools enforce 'zero tolerance' discipline, strict rules and dress codes, high exclusion rates, league tables that test rote learning more than creative study, and pressure to conform to improve the school's ratings. Free speech and political debate are closed down (Faure Walker, 2019). However, research with young children, who learn more in their first four years than they will in the rest of their lives (Gardner, 1993) shows ontological processes of learning that are very different from the functionalist, epistemic view. From birth, our lifelong scientific and moral learning is mainly through our bodies, relationships and practical experiences (Archer, 2000; Gopnik, 2010). Durkheim's view, that everything we know is taught through words, has been questioned. Where does morality comes from? And why do we bother to adopt it, if it is synthetic, alien to our innate human nature, and has to be wholly acquired and enforced through socialization? Instead, babies aged from three months seem to show an innate, rudimentary sense of justice and goodness, long before these can be explained to them in words (Gopnik, 2010; Bloom, 2014; Alderson, 2013b). Instead of enforced unquestioning obedience and compliance, the morality of independent thought and, if need be, of courageous protest can work to prevent cruelty and oppression, for example, of fascism (Bauman, 2003).

When PK theorists overlook learners' agency, they suggest a passive emptyvessel model of students being filled with knowledge, whereas critical realism researches active creative learning in the continual knowers-known dialectic (Archer, 2000; Alderson, 2019). Instead of schools trying to teach children 'to learn right from wrong', effective schools draw on, nurture and help young children to develop the deep experiential moral knowledge they already have, as well as their highly effective methods of partly self-directed learning (Donaldson, 1978; Gardner, 1993; Alderson, 2013a, 2019). This section has looked at the need, when understanding knowledge, to consider the agency of the knowers. The next section reviews how social contexts are also vitally important. 


\section{Social and cultural contexts}

PK theory in the Durkheim tradition attributes power more to structures and cultural forms than to agents. Yet although natural structures have power (volcanoes), social structures and cultural forms, including knowledge, are latent, inert positions and relations until they are enacted and reconstructed through human agents (Archer, 2000; Bhaskar, 1998, 2008; Porpora, 2015). Paradoxically, libraries are most productive when they are absent, when their borrowed books and other resources are being read mainly outside the premises (by human agents). Countless past ideas emerge into new knowledge only within knowers' minds. Like fire, knowledge is latent potential until it ignites through the friction between thinkers and ideas within human relationships, when people read, write, talk, teach, learn, research, repeat and transform knowledge.

Knowledge serves power when it is connected into powerful systems. Through the centuries, British schools and universities have trained students for the Church, the military, the civil service and government, although seldom teaching scientific PK theories. Ironically, the knowledge directly connected to the greatest power was unleashed by the industrial revolution and developed in factories outside the universities and the ruling class (Trinder, 2013). Contrary to PK theory, technology and industry are informed as much by everyday practical knowledge and experiment as by theorems. And although Bernsteinian bounded single-discipline knowledge is supposed to be the most powerful, interdisciplinary science produces by far the highest impact papers and wins the most patents (Syed, 2019).

PK theorists regard predictive scientific theorems or laws as the most powerful form of knowledge (Young and Muller, 2016: 118-19), leading them to favour the natural sciences and leading them away from considering knowledge in unpredictable social and everyday contexts. Yet these powers only work predictably in closed systems, which are governed by a single power (Bhaskar, 1998). However, we live in open systems of many competing forces or powers. Possibly the most universal natural power, gravity, for example, is counteracted by air currents, jet engines and bird flight. Social life and social justice are still more complex, when social, cultural, biological, political and economic influences all compete or converge, rarely with precisely predictable effects.

The concept of PK reifies knowledge. To reify is to transform human activities and relationships (such as of knowing) into an impersonal powerful thing: powerful knowledge. Critical theory traces how people become alienated if their work is reified, so that they feel split and disintegrated (ibid.). Reified PK can become a commodity to be priced, bought and sold, while the people concerned may be treated as objects. For example, teachers and students are manipulated through enforced curricula, exam systems and school league tables. Global publishing companies market knowledge exchange in teaching and testing materials and technologies. These increasingly lead to students being taught to the test in the currency of easily tested, standardized, PKtype atomized facts and theories (critiqued by Ainley, 2016; Ball, 2013; Benn and Downs, 2016; Scott, 2010). The systems can undermine learners' self-confidence and self-belief (Reay, 2017). They discourage creativity and critical inquiry, experiment and learning from making mistakes, which cannot be measured easily, if at all. Such determinism through 'manipulation, mystification, legitimation, naturalization, persuasion and argument [is] intimately allied to the use of power and influence' (Archer, 1988: xvi).

PK is also fetishized or invested with magical power (Marx, 1990: 165), such as if it is assumed to produce social justice (Young and Muller, 2016; Muller and Young, 2019). Yet the actual effect of a fetish can be to disempower and fragment human agency and morality. New possibilities may be closed down when teachers' and students' agency and power are taken from them, and when the fetish (such as PK) seems to possess 'a 
life of [its] own, external to and coercing the individual' (Bhaskar, 1998: 31). People are then alienated in the sense of being separated from their essential nature and from justice. In schools, social relationships between people may be turned into economic relationships between things, in traded commodities such as exam papers and scores. School students are invisible workers, since their learning is not recognized or paid as productive work, although societies' future existence and prosperity depend upon it. Their years of learning may be recognized only in the proxy and fetish of exam results. The often-deceptive scores may unfairly be used to reward or punish schools, price their value, and award lower funding to schools most in need of support. The scores encourage gaming, such as when schools exclude students who are likely to fail exams in order falsely to improve school ratings (Muller, 2018). Vast sums are diverted into managing, recording and researching the metrics of schooling systems. To score highly in the core subjects, most closely connected to PK, schools neglect and underfund the arts, sports, technical work, the social sciences and humanities (Benn and Downs, 2016).

Knowledge depends on social contexts, which influence whether it contributes to powerful effects. Thousands of research scientists are working together internationally on what could be seen as the most powerful collaborative knowledge ever produced. It has the highest intellectual status as valid, objective, credible, 'hard' science of crucial global importance, as 98 per cent of specialist scientists agree. Yet these scientists' reports and urgent recommendations have almost no power, so far, to change the related policies on its core theme: climate change (Bhaskar et al., 2010; IPCC, 2018).

This failure confirms that knowledge alone is powerless. Its authority is ascribed, not intrinsic. Highly knowledgeable individuals may be powerless, from Socrates in the prison forced to drink hemlock, to Solzhenitsyn in the psychiatric ward. Indeed, they became vulnerable because of their outstanding critical knowledge, which could not defend them. Knowledge cannot be powerful if those who advance it are not.

There is hope of promoting social justice through advancing equal opportunities to access PK (Moore, 2013; Wheelahan, 2010; Young and Muller, 2016). Equal opportunities differ from actual equal resources and compensatory support, and disadvantaged students may be blamed for seeming to fail to use the opportunities when social inequalities prevent them from succeeding, in an ethos that favours progress through individual effort rather than through restructuring social injustices (Ainley, 2016; Alderson, 2016; Ball, 2013; Bhaskar, 2008; Williams, 2018). The recommended avoidance of everyday knowledge by PK theorists increases disadvantages when it alienates many students, so preventing them from developing their early passion for learning, as has long been known (Donaldson, 1978; Gardner, 1993).

In Durkheimian functionalism, states and schools promote collective norms, even when the norms reinforce inequality and injustice, as in present education systems (Ainley, 2016; Ball, 2013; Benn and Downs, 2016; Reay, 2017). Gouldner (1977) analysed how functionalism is inexorably utilitarian when it values each part according to its functioning or utility. Power is then connected to wealth and control more than to the power of wisdom, justice and compassion. PK-related power is implicitly wholly positive. However, critical realism distinguishes between two forms of power: oppressive destructive power2, versus liberating creative fulfilling power1. Power2 morality promotes order and efficiency but not justice, whereas critical realism aims to promote justice and freedom through transforming the predominance of power2 into power1 (Bhaskar, 2008).

Social change works mainly at everyday practical levels in the physical and social world. For instance, new laws on health and safety, or ways to conserve energy cannot work on an abstract general level. They have powerful effects only when many people 
adapt and conform to detailed new standards in everyday life. Contrary to PK theory, power inheres less in types of knowledge than in how ideas contribute to shaping adults' and children's everyday beliefs and behaviours. Attempts to separate academic from everyday knowledge therefore seem unhelpful and unrealistic. Schools' informal curricula may more powerfully change lives than formal instruction can, when they convey unspoken values, such as of inclusion or exclusion, respect or disrespect, through everyday school routines (Alderson, 2013a). PK theory raises questions about how social and cultural contexts and relations affect the influence that knowledge may or may not have.

\section{The application of knowledge}

Besides knowers acquiring knowledge within different social contexts, whether knowledge will have powerful effects also much depends on how it is actually promoted and applied. Types of powerful knowledge will be reviewed for their success or failure in influencing society.

The most successfully effective knowledge differs from the PK model of scientifically valid true knowledge. The latter often fails to influence, as noted (IPCC, 2018, for example), whereas false information and sophistry often succeed (Stanley, 2018; Weatherall et al., 2018). Misleading advertisements, news reports, emails and tweets shape the beliefs, behaviours and votes of millions of people. Although these messages meet none of the criteria of PK, they influence public opinion, which can create or destroy governments and global corporations (Bogdanor, 2009; Harvey, 2016; Picketty, 2017). Negative power2 knowledge imposes on vulnerable groups when online neuro-marketing induces viewers to feel stressed, insecure, depressed and worthless, so that they are more open to being powerfully persuaded by deluges of advertising (Morin and Renvoise, 2018).

The most powerful global discipline, neoclassical economics, claims to be a (closed-system) science. Yet it fails as a science, in that: few economists can predict regular financial crashes; economics is based on disputed misleading models of human nature as greedy individualism; and, counterproductively, neoclassical economics discourages fair competition, distribution and investment on which social prosperity and peace depend (Harvey, 2016; Picketty, 2017; Raworth, 2017).

Political leaders, among the most powerful members of society, tend to be valued for their ignorance. Newly appointed ministers of, say, health or transport, are not expected to be expert in their new area. Instead they should be open-minded, able to take advice and adjudicate disinterestedly between many opposing views. Prior knowledge here is associated with biased, narrow understanding that could complicate the government's priorities (Bogdanor, 2009).

Ignorance may involve not absence of knowledge, but the wrong kind of knowledge. Many voters believe they are highly informed, as the Brexit debates and Trump rallies showed. To define powerful knowledge as 'reliable' knowledge, Young (2009: 14) disregards influential gossip and rumour. Memories shift and fade. Even scientific research reports are often unreliable. Clinical research costs nearly $\$ 200$ billion annually, but half the research remains unpublished and weak design means that an estimated 85 per cent of the millions of published clinical research papers are worthless (Macleod et al., 2014). University experts promote outdated, dangerously misleading knowledge, such as the 'facts' still given to millions of people in unhealthy diet advice (Taubes, 2018). Applied science has brought great wealth and prosperity, but it also informs industries that greatly damage living species and the environment 
(IPCC, 2018). Science can be harnessed to promote social justice and wellbeing but only if its application is informed by moral concern for the well-being of all people and the natural world (Hansen et al., 2013; IPCC, 2018; Midgley, 1989).

\section{Conclusion}

Knowledge can record and explain how greenhouse gas emissions heat up the atmosphere and induce climate change with innumerable local and global effects. It can explain how the processes may be increased or delayed. Yet knowledge alone has no power to alter the processes, and 'powerful knowledge' is an oxymoron. Any power depends on how human agents decide to understand and apply the knowledge within their social contexts. Some climate scientists, in despair about the global inaction, see more hope of being effective by leaving their laboratories and becoming political activists (Hansen et al., 2013).

The universities' pursuit of knowledge as their priority, advocated by PK theorists, has been described as 'the key disaster of our times', and the cause of all the other crises (Maxwell, 2014: 5). We have been diverted from the primary concern: to learn how to tackle global problems of everyday living 'in more intelligent, humane and effective ways' (ibid.). The scientific model of careful observation and analysis of natural laws is vital. Yet social progress also depends on knowledge of the social sciences and humanities beyond the PK emphasis on natural science.

Objectivity is necessary as open minded, fair attention to all relevant matters. But objectivity prevents social progress when it attempts, in the 'value-free' PK model, to avoid discerning, moral assessment that attends to values, hopes, suffering and flourishing (Sayer, 2011). Supposedly value-free pursuit of knowledge can be distorted into diverting half of all UK scientific research funds into the 'defence' and arms industries, and away from life-enhancing research (Bourke, 2014). Muller and Young (2019: 210) agree that they do not yet say 'which knowledge can be powerful' or how to devise curricula that avoid 'boring or alienating' many students. PK theorists possibly mainly stay within abstract knowledge debates that evade the related knowers, social contexts and practical applications, because the PK theory itself denies the power and relevance of these realities. The functionalism and science-orientation of PK theory may also divert researchers away from criticizing present injustices in schools and society into describing and analysing processes. Critical realists refer to veils and webs of illusion at the threshold of reality. These obscure and protect entities by keeping them intact. PK theory acts as a veil or illusion. The veil can be a starting point for immanent (internal, inherent, pervasive) critique, which analyses an idea in its internal construction and problems. This can reveal how an idea 'unwittingly expresses and presupposes the very content it would deny' (Bhaskar, 2002: 5-6). PK theory can then be seen to misrepresent power as abstract, inhuman, apolitical, seemingly neutral, and remote from social change and progress. This serves powerful groups who want to maintain present unjust, inefficient systems, as when policymakers and theorists constrict and impose on to schools narrow PK curricula. Debates about the fetish of PK's contents divert attention from examining its confused meaning, whose interests it serves, and 'the associated chains of errors, contractions and denials' (ibid.: 27).

Instead of the pursuit of knowledge as an end in itself, in universities, schools and everyday life, we all urgently need to study wisdom, searching for ways to understand and resolve the most pressing global problems, and encourage progress towards a better, wiser world (Alderson, 2016; Maxwell, 2014; Midgley, 1989; Shefer et al., 2018). This task will involve studying the humanities, and social and natural sciences, and also 
nurturing all children's critical faculties and early love of learning. Besides knowledge, everyone needs critical skills to scrutinize and judge propaganda, fake news and misleading authorities, guided by their values and everyday expertise. For example, critical histories of the British Empire (Tharoor, 2017) and the industrial revolution (Trinder, 2013) - their failings as well as their triumphs - would consider centuries of the use and misuse of power. Students could then consider what reparations should be made to the countries that Empire and industry have plundered and polluted. Students would learn and question how leaders repeatedly extend their power2 by fostering division of societies into 'us' and 'them', by evoking nostalgia for a mythic past, and by dismantling public welfare and unity (Stanley, 2018).

Social justice involves closing the great gap between the achievement levels of higher and lower attaining students. PK curricula, however, promote teaching content that discourages lower attaining students. They also undervalue practical and political school subjects that can inform all students, schools and society how to promote social justice. All students need education that combines social usefulness with personal relevance, with access to the knowledge, values and skills that will help them through their personal and working lives. They need to know that their lessons are personally relevant, accessible and meaningful. Students willingly do much hard, boring work, provided they see how this can help them towards fuller understanding and enjoyment of their learning or work. To respect this human motivation, all concerned in school education need to share in choosing and creating curricula aimed to support personal fulfilment and the good society (Ainley, 2016; Alderson, 2003, 2013b, 2016; Fielding and Moss, 2011; Manyukhina and Wyse, 2019; White, 2018: 332).

\section{Acknowledgements}

Thanks to all the children and adults who have helped with my research, and to the two anonymous reviewers.

\section{Notes on the contributor}

Priscilla Alderson is Professor Emerita of Childhood Studies at the UCL Institute of Education. She taught in London schools and has worked in children's rights advocacy and, since 1983, in sociology research. Recent books include a new Kindle edition of Enabling Education: Experiences in special and ordinary schools (with Christopher Goodey; Tufnell Press, 2018), The Politics of Childhoods Real and Imagined (Routledge, 2016), Childhoods Real and Imagined (Routledge, 2013) and Learning and Inclusion: The Cleves School experience (Routledge Revivals, 2013).

\section{References}

Ainley, P. (2016) Betraying a Generation: How education is failing young people. Bristol: Policy Press.

Alderson, P. (2003) 'Institutional rites and rights: A century of childhood'. Inaugural professorial lecture, Institute of Education, London, 4 June 2003.

Alderson, P. (2013a) Learning and Inclusion: The Cleves School experience. London: Routledge.

Alderson, P. (2013b) Childhoods Real and Imagined: Volume 1: An introduction to critical realism and childhood studies. London: Routledge.

Alderson, P. (2016) The Politics of Childhoods Real and Imagined: Volume 2: Practical application of critical realism and childhood studies. London: Routledge.

Alderson, P. (2019) 'Powerful knowledge and the curriculum: Contradictions and dichotomies'. British Educational Research Journal, 1-18. Online. https://doi.org/10.1002/berj.3570 (accessed 25 November 2019). 
Archer, M.S. (1988) Culture and Agency: The place of culture in social theory. Cambridge: Cambridge University Press.

Archer, M.S. (2000) Being Human: The problem of agency. Cambridge: Cambridge University Press.

Ball, S.J. (2013) Education, Justice and Democracy: The struggle over ignorance and opportunity. London: Centre for Labour and Social Studies.

Barad, K. (2007) Meeting the Universe Halfway: Quantum physics and the entanglement of matter and meaning. Durham, NC: Duke University Press.

Bauman, Z. (2003) Modernity and the Holocaust. Cambridge: Polity Press.

Benn, M. and Downs, J. (2016) The Truth about Our Schools: Exposing the myths, exploring the evidence. London: Routledge.

Bernstein, B. (2000) Pedagogy, Symbolic Control and Identity: Theory, research, critique. Rev. ed. Lanham, MD: Rowman and Littlefield.

Bhaskar, R. (1998) The Possibility of Naturalism: A philosophical critique of the contemporary human sciences. 3rd ed. London: Routledge.

Bhaskar, R. (2002) From Science to Emancipation: Alienation and the actuality of enlightenment. London: SAGE Publications.

Bhaskar, R. (2008) Dialectic: The pulse of freedom. London: Routledge.

Bhaskar, R., Frank, C., Høyer, K.G., Næss, P. and Parker, J. (eds) (2010) Interdisciplinarity and Climate Change: Transforming knowledge and practice for our global future. London: Routledge.

Bloom, P. (2014) Just Babies: The origins of good and evil. New York: Broadway Books.

Bogdanor, V. (2009) The New British Constitution. Oxford: Hart.

Bourke, J. (2014) Wounding the World: How military violence and war-play invade our lives. London: Virago.

Brighouse, H. (2000) School Choice and Social Justice. Oxford: Oxford University Press.

Deng, Z. (2015) 'Content, Joseph Schwab and German Didaktik'. Journal of Curriculum Studies, 47 (6), 773-86.

Donaldson, M. (1978) Children's Minds. Glasgow: Fontana.

Durkheim, E. (1995) The Elementary Forms of Religious Life. Trans. Fields, K.E. New York: Free Press.

Faure Walker, R. (2019) 'The UK's Prevent counter-terrorism strategy appears to promote rather than prevent violence'. Journal of Critical Realism, 18 (5), 487-512.

Fielding, M. and Moss, P. (2011) Radical Education and the Common School: A democratic alternative. London: Routledge.

Gardner, H. (1993) The Unschooled Mind: How children think and how schools should teach. London: Fontana.

Gericke, N., Hudson, B., Olin-Scheller, C. and Stolare, M. (2018) 'Powerful knowledge, transformations and the need for empirical studies across school subjects'. London Review of Education, 16 (3), 428-44.

Gopnik, A. (2010) The Philosophical Baby: What children's minds tell us about truth, love, and the meaning of life. New York: Picador.

Gouldner, A.W. (1977) The Coming Crisis of Western Sociology. London: Heinemann.

Hansen, J., Kharecha, P., Sato, M., Masson-Delmotte, V., Ackerman, F., Beerling, D.J., Hearty, P.J., Hoegh-Guldberg, O., Hsu, S.-L., Parmesan, C., Rockstrom, J., Rohling, E.J., Sachs, J., Smith, P., Steffen, K., Van Susteren, L., Von Schuckmann, K. and Zachos, J.C. (2013) 'Assessing "dangerous climate change": Required reduction of carbon emissions to protect young people, future generations and nature'. PLoS ONE, 8 (12), Article e81648, 1-26. Online. https://doi.org/10.1371/journal.pone.0081648 (accessed 26 November 2019).

Harvey, D. (2016) The Ways of the World. New York: Oxford University Press.

Hoadley, U., Sehgal-Cuthbert, A., Barrett, B. and Morgan, J. (2019) 'After the knowledge turn? Politics and pedagogy'. Curriculum Journal, 30 (2), 99-104.

IPCC (Intergovernmental Panel on Climate Change) (2018) Global Warming of $1.5^{\circ} \mathrm{C}$ : Summary for policymakers. Geneva: Intergovernmental Panel on Climate Change. Online. https://report.ipcc.ch/sr15/pdf/sr15_spm_final.pdf (accessed 26 November 2019).

Lambert, D. (2018) 'Editorial: Teaching as a research-engaged profession: Uncovering a blind spot and revealing new possibilities'. London Review of Education, 16 (3), 357-70.

Lukes, S. (2005) Power: A radical view. 2nd ed. Basingstoke: Palgrave Macmillan.

Macleod, M.R., Michie, S., Roberts, I., Dirnagl, U., Chalmers, I., loannidis, J.P.A., Al-Shahi Salman, R., Chan, A.-W. and Glasziou, P. (2014) 'Biomedical research: Increasing value, reducing waste'. The Lancet, 383 (9912), 101-4.

Manyukhina, Y. and Wyse, D. (2019) 'Learner agency and the curriculum: A critical realist perspective'. Curriculum Journal, 30 (3), 223-43. 
Marx, K. (1990) Capital: Volume 1: A critique of political economy. Trans. Fowkes, B. London: Penguin.

Maxwell, N. (2014) How Universities Can Help Create a Wiser World: The urgent need for an academic revolution. Exeter: Imprint Academic.

Midgley, M. (1989) Wisdom, Information and Wonder: What is knowledge for? London: Routledge.

Molyneux, J. (2012) The Point is to Change It! An introduction to Marxist philosophy. London: Bookmarks.

Moore, R. (2013) 'Social realism and the problem of the problem of knowledge in the sociology of education'. British Journal of Sociology of Education, 34 (3), 333-53.

Morin, C. and Renvoise, P. (2018) The Persuasion Code: How neuromarketing can help you persuade anyone, anywhere, anytime. Hoboken, NJ: Wiley.

Muller, J.Z. (2018) The Tyranny of Metrics. Princeton: Princeton University Press.

Muller, J. and Young, M. (2019) 'Knowledge, power and powerful knowledge re-visited'. Curriculum Journal, 30 (2), 196-214.

Peters, R.S. (1972) Reason, Morality and Religion. London: Friends Home Service Committee.

Piketty, T. (2017) Why Save the Bankers? And other essays on our economic and political crisis. Boston: Mariner Books.

Porpora, D.V. (2015) Reconstructing Sociology: The critical realist approach. Cambridge: Cambridge University Press.

Raworth, K. (2017) Doughnut Economics: Seven ways to think like a 21st-century economist. London: Random House.

Reay, D. (2017) Miseducation: Inequality, education and the working classes. Bristol: Policy Press.

Sayer, A. (2011) Why Things Matter to People: Social science, values and ethical life. Cambridge: Cambridge University Press.

Scott, D. (2010) Education, Epistemology and Critical Realism. London: Routledge.

Shefer, T., Hearn, J., Ratele, K. and Boonzaier, F. (eds) (2018) Engaging Youth in Activism, Research, and Pedagogical Praxis: Transnational and intersectional perspectives on gender, sex, and race. New York: Routledge.

Spyrou, S. (2018) Disclosing Childhoods: Research and knowledge production for a critical childhood studies. London: Palgrave Macmillan.

Stanley, J. (2018) How Fascism Works: The politics of us and them. New York: Random House.

Syed, M. (2019) Rebel Ideas: The power of diverse thinking. London: John Murray.

Taubes, G. (2018) The Case against Sugar. London: Portobello Books.

Tharoor, S. (2017) Inglorious Empire: What the British did to India. London: Hurst and Company.

Trinder, B. (2013) Britain's Industrial Revolution: The making of a manufacturing people, 1700-1870. Lancaster: Carnegie Publishing.

Weatherall, J.O., O'Connor, C. and Bruner, J.P. (2018) 'How to beat science and influence people: Policy makers and propaganda in epistemic networks'. Computer Science, 1-26. Online. DOI: 10.1093/bjps/axy062 (accessed 26 November 2019).

Weber, M. (2013) Economy and Society. Ed. Roth, G. and Wittich, C. Berkeley: University of California Press.

Wheelahan, L. (2010) Why Knowledge Matters in Curriculum: A social realist argument. London: Routledge.

White, J. (2018) 'The weakness of "powerful knowledge"'. London Review of Education, 16 (2), 325-35

Williams, J. (2018) "It Just Grinds You Down": Persistent disruptive behaviour in schools and what can be done about it. London: Policy Exchange.

Young, M. (2008) Bringing Knowledge Back In: From social constructivism to social realism in the sociology of education. London: Routledge.

Young, M. (2009) 'What are schools for?'. In Daniels, H., Lauder, H. and Porter, J. (eds) Knowledge, Values and Educational Policy: A critical perspective. London: Routledge, 10-18.

Young, M. (2014) 'What is a curriculum and what can it do?'. Curriculum Journal, 25 (1), 7-13.

Young, M., Lambert, D., Roberts, C. and Roberts, M. (2014) Knowledge and the Future School: Curriculum and social justice. London: Bloomsbury Academic.

Young, M. and Muller, J. (2016) Curriculum and the Specialization of Knowledge: Studies in the sociology of education. London: Routledge. 